\title{
EPIGASTRIC HETEROPAGUS TWINS
}

\section{Sangita Chauhan ${ }^{1}$, Shreya Sharma *2, Preksha Sharma ${ }^{3}$, Neeru Sharma ${ }^{4}$.}

${ }^{1}$ Senior Professor, Department of Anatomy, SMS Medical College, JLN Marg, Jaipur, India.

${ }^{2}$ M.Sc.(Med.)Anatomy, Department of Anatomy, SMS Medical College, JLN Marg, Jaipur, India.

${ }^{3}$ M.S. (Anatomy), Department of Anatomy, SMS Medical College, JLN Marg, Jaipur, India.

${ }^{4}$ Consultant Gynaecologist, Neeru Clinic, 6-Gopinath Marg, M.I. Road, Jaipur, India.

\section{ABSTRACT}

Epigastric Heteropagus Twinning is a rare congenital anomaly, constituting 1-2\% cases of conjoined twins. In this type of twinning, the dependent portion (parasite) is attached to the epigastric region of the fully formed host (autosite) and derives nutrition from it. We report a case of Epigastric Heteropagus Twins born in a private nursing home in Jaipur, Rajasthan. The parasite exhibits rudimentary lower limbs and male external genitalia. It was a case of abortive twinning. The twins were separated and brought to the Department of Anatomy, SMS Medical College, Jaipur for academic interest. The blood supply of the parasite was found to be derived from falciform ligament.

KEY WORDS: Parasitic Twins, EHT, Conjoined Twins.

Address for Correspondence: Dr. Shreya Sharma, 86/25, Kumbha Marg, Pratap Nagar, Sanganer, Jaipur (Rajasthan) 302033, +91-9983469469 E-Mail: drshreyasharma@live.com

\begin{tabular}{|c|c|c|}
\hline \multicolumn{3}{|c|}{ Access this Article online } \\
\hline \multirow{2}{*}{$\begin{array}{l}\text { Quick Response code } \\
\text { DOI: } 10.16965 / \text { iiar.2017.165 }\end{array}$} & \multicolumn{2}{|c|}{$\begin{array}{l}\text { Web site: International Journal of Anatomy and Research } \\
\text { ISSN 2321-4287 } \\
\text { www.ijmhr.org/ijar.htm }\end{array}$} \\
\hline & $\begin{array}{l}\text { Received: } 28 \text { Feb } 2017 \\
\text { Peer Review: } 01 \text { Mar } 2017 \\
\text { Revised: None }\end{array}$ & $\begin{array}{l}\text { Accepted: } 03 \text { Apr } 2017 \\
\text { Published (O): } 30 \text { Apr } 2017 \\
\text { Published (P): } 30 \text { Apr } 2017\end{array}$ \\
\hline
\end{tabular}

\section{INTRODUCTION}

Asymmetrical Conjoined Twinning is one of the rarest congenital anomalies. It constitutes $1-2 \%$ of the conjoined twins. In Epigastric Heteropagus Twinning, the dependent portion (parasite) is attached to the epigastric region of the host (autosite) and is smaller than it. (1) Although parasitic twins are often assumed to be monozygotic, there is no confirmation to validate this hypothesis. Epigastric Heteropagus Twins (EHT) are different from symmetrical twins in many ways: EHT shows male preponderance. Any major connection of bowels, vessels or bones is also not found. These characteristics suggests that this interesting malformation might be caused due to fusion of two fertilized ova andatrophy of one fetus. ${ }^{(2)}$ Another hypothesis suggests that EHT occurs due to incomplete cleavage of embryo at two weeks of gestation. However, the cranial part of one of these monozygotic twins undergoes selective atrophy following an ischaemic insult in the early gestational period [1].

\section{CASE REPORT}

We report a case of abortive twinning of a full term male boy born at a private nursing home in Jaipur, Rajasthan. The baby had an undeveloped parasite attached to his epigastric region. The child was malnourished and underweight $(2.6 \mathrm{~kg})$. His mother was underweight and reported a history of one previous miscarriage. Father and other sibling of the child were healthy and normal. 
On examination, there was a mass attached to the abdomen of the child having rudimentary lower limbs and external genitalia. The right limb was comparatively well formed than the left limb. Incomplete formation of hip joint, knee joint and ankle joint was seen in the right limb, whereas the hip joint and knee joint were absent in the left limb. The scrotum of the host was not developed, the penis was however, fully developed. The natal cleft was not developed when seen from posterior aspect.

The parasite was separated from the autosite after his death and brought to the Department of Anatomy, SMS Medical College, for academic interest. On dissection, the blood supply of the parasite was found to be derived from falciform ligament.

Fig. 1: Anterior view of the parasite separated from the autosite.

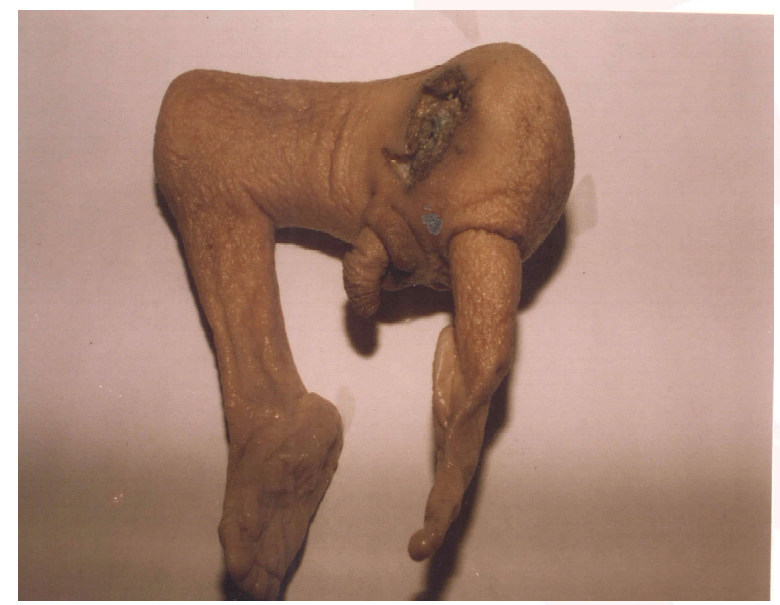

Rudimentaty lower limbs and male external genitalia is visible. The right limb is comparatively more developed than the left one. Hip joints are not formed on both sides. Femur and Knee joint did not develop on the left side.

Fig. 2: Posterior view of the parasite separated from autosite. Posterior natal cleft is not formed.

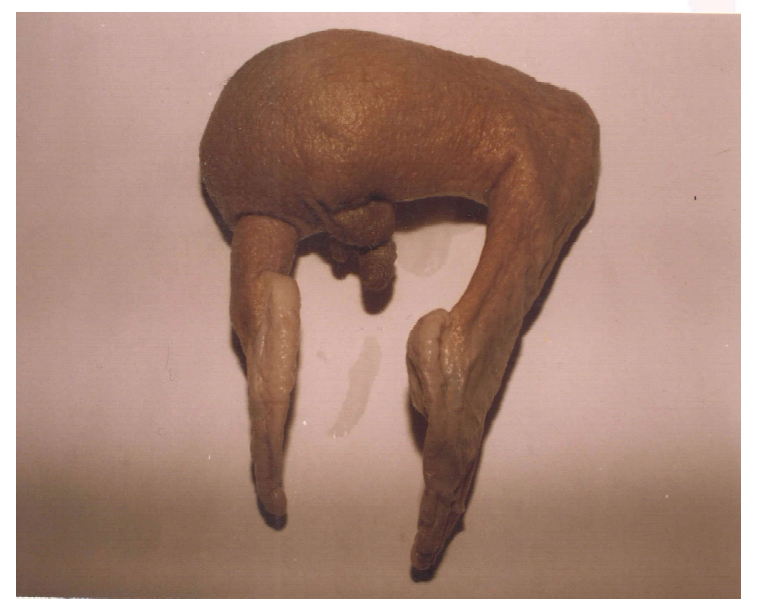

Int J Anat Res 2017, 5(2.1):3750-52. ISSN 2321-4287

\section{DISCUSSION}

Heteropagus or Parasitic twinning is a rare occurrence where the dependent portion (parasite) is attached to the fully formed normal child (autosite). As the name suggests, the parasite is completely dependent on autosite for its nutrition. This kind of twinning is extremely rare: one in 2 million live births [3]. The parasite is attached to the epigastric or hypogastric region of the autosite in most of the cases. It might possess well formed limbs and trunk but it is mostly acephalic and acardiac. Some cases with rudimentary heart, head and thorax have also been reported [4]. Parasitic twinning shows male preponderance [1]. The parasite may have variable components. However, the limbs are most commonly developed, when present. Hind limbs are better formed as compared to fore limbs. Variable lengths of genitourinary system and intestines are also found [5]. In our case, the parasite had rudimentary limb with male external genitalia. The blood supply was derived from falciform ligament, which happens in most of the cases [6].

The etiology of conjoined twinning is not very clear. In 2000, Spencer reviewed 1800 publications about the pathological and embryological anatomy of conjoined twins. His study provided convincing evidence that conjoined twins result from secondary union of two monovular embryonic discs, thus confirming the "fusion" theory [7]. Another theory suggests that conjoined twins are basically monozygotic twins, with incomplete division ("fission") of inner cell mass. The two embryos thus formed are joined by inner cell mass. Incomplete division of the embryo post 13th day of conception leads to the formation of conjoined twins. Some authors suggest that selective ischaemic damage of the fetus in utero leads to the death or partial resorption of one of the twins, which later gets attached to the fully developed twin, leading to conjoined twinning $[8,9]$.

Epigastric heteropagus twinning is a rare case. The prognosis and outcome of the separation of the twins depends on the extent of visceras they share and other anomalies. However, early diagnosis, intensive prenatal management and proper route of delivery are vital for the successful treatment of EHT patients [10]. 


\section{ACKNOWLEDGEMENTS}

The author would acknowledge the support and guidance extended by Dr. Neeru Sharma and her team at Neeru Clinic in identifying and diagnosing the rare anomaly.

\section{Conflicts of Interests: None}

\section{REFERENCES}

[1]. Gupta DK, Lall A, Bajpai M. Epigastric heteropagus twins-a report of four cases. Pediatric surgery international. 2001 Jul 8;17(5):481-2.

[2]. Hwang E.H., Han S.J., Lee J.-S., Lee M.K. An unusual case of monozygotic epigastric heteropagus twinning. Journal of Pediatric Surgery. 1996;31(10): 1457-1460.

[3] O'Neill Jr JA, Holcomb III GW, Schnaufer L, et al. Surgical experience with thirteen conjoined twins. Ann Surg 1988;208:299-312.

[4]. Ribeiro RC, Maranhão RF, Moron AF, et al. Unusual case of epigastric heteropagus twinning. J Pediatr Surg. 2005;40:39-41.
5]. Kanamori $Y$, Tomonaga $T$, Sugiyama $M$, et al. Bizarre presentation of epigastric heteropagus: report of a case. Surg Today. 2006;36:914-8.

[6]. Cury EK, Schraibman V. Epigastric heteropagus twinning. J Pediatr Surg. 2001;36:11.

[7]. Spencer R. Theoretical and analytical embryology of conjoined twins: part I: embryogenesis.Clin Anat. 2000;13(1):36-53.

[8]. Zimmerman AA. Embryologic and anatomic considerations of conjoined twins. National Foundation. 1967;3:18.

[9]. Spencer R. Parasitic conjoined twins: external, internal (fetuses in fetu and teratomas), and detached (acardiacs) Clin Anat. 2001;14:428-44.

[10]. Bhansali M, Sharma DB, Raina VK. Epigastric heteropagus twins: 3 cases reports with review of literature. Journal of Pediatric Surgery. 2005;40(7):1204-8.

How to cite this article:

Sangita Chauhan, Shreya Sharma, Preksha Sharma, Neeru Sharma. EPIGASTRIC HETEROPAGUS TWINS: A CASE REPORT. Int J Anat Res 2017;5(2.1):3750-3752. DOI: 10.16965/ijar.2017.165 